\title{
FOREWORD
}

\section{International Law In Practice}

The 112th Annual Meeting of the Society began on a somber note, as we mourned the untimely loss of Past President David D. Caron (1952-2018), a longtime leader of the Society, and a colleague, mentor, and friend to many. David last appeared before the Society to deliver the Brower Lecture at the 2017 Annual Meeting, and was very much a presence this year as we dedicated the Annual Meeting - and these Proceedings - to his memory.

This year's Annual Meeting theme, "International Law in Practice," invited the conferees to reflect on the myriad ways in which practice shapes, and is shaped by, the evolving meaning, application, and reception of international law. These reflections could not fail to be informed, both implicitly and explicitly, by the profound shifts in U.S. policy with regard to international agreements and legal institutions that had taken place over the previous fifteen months, and more broadly, toward international law as a source of normative constraints on state action.

Such concerns played out over the course of many of the fifty substantive sessions, including discussions of "The Counselor in International Law"; "Operationalizing International Law: Beyond the State"; "Teaching International Law in an Age of Global Retreat from International Agreements"; "Legal Restrictions on Warfare Technology"; "Global Governance of Migration"; "The Role of Non-State Actors in Implementing the Paris Agreement on Climate Change"; and "Rulemaking by International Organizations."

The current challenges to international legal regimes also were addressed in two "late-breaking" panels, on "Twenty-first Century Misinformation Campaigns" and "Revisiting the Multilateral Trading System," as well as in our Closing Plenary on "The Future of Multilateralism."

Conference plenaries began on Wednesday with the 20th Annual Grotius Lecture - presented, as always, in cooperation with ASIL Academic Partner American University Washington College of Law. This anniversary lecture was delivered by Judge Joan E. Donoghue of the International Court of Justice, whose address on "International Adjudication: Peaks, Valleys, and Rolling Hills" considered the Annual Meeting theme as it relates to the changing nature of practice before international courts. The Distinguished Discussant, Dapo Akande, Professor of Public International Law at Oxford University, provided an engaging and learned response.

On Thursday, the Society held its third annual Assembly, featuring honors, awards, memorials, and the election of the incoming leadership. The program opened with a moving tribute to David Caron by his friend, mentor, and colleague, ASIL Past President Charles N. Brower. The keynote address was delivered by Sir Christopher Greenwood, on "The Practice of International Law: Threats, Challenges and Opportunities." President Lucinda A. Low presented the Society's three highest honors: the Manley O. Hudson Medal to former ASIL President Peter Trooboff (Senior Counsel, ASIL Law Firm Member Covington \& Burling LLP, and Past President of the Society); the Goler T. Butcher Medal to Justice Rosalie Silberman Abella of the Supreme Court of Canada; and the Honorary Member Award to Olufemi Elias, UN Assistant Secretary-General and Registrar of the International Residual Mechanism for Criminal Tribunals. The Assembly concluded with the passing of the gavel to the forty-eighth president of the Society, Professor Sean D. Murphy. 
The Friday evening keynote was given by Stephen J. Rapp, former U.S. Ambassador-at-Large for War Crimes Issues, on "International Criminal Justice from the Ground Up."

Other highlights of the meeting included:

The Hudson Medal Luncheon, a standing-room-only affair, featuring a conversation between Hudson Medal recipient Peter Trooboff and Harold Hongju Koh, the Sterling Professor of International Law at Yale Law School and a Counsellor of the Society;

The Sixth Annual Charles N. Brower Lecture on International Dispute Resolution, delivered by Meg Kinnear, Secretary-General of the International Centre for Settlement of Investment Disputes, on "Policy and Progress: Seeking Consensus in ISDS Rules Reform," discussing the goals of the soon-to-be-proposed amendments to the ICSID rules, and the process for considering comments from States and the public;

The 25th Annual Women in International Law Interest Group (WILIG) Luncheon, which included remarks by Justice Abella and the presentation of the Prominent Woman in International Law Award to Maxine Marcus, Director of the Transitional Justice Clinic; and

The Third Annual Detlev F. Vagts Roundtable on Transnational Law, featuring a discussion of "Data Protection in a Global World," by a distinguished panel convened by Professor Joel Reidenberg of ASIL Academic Partner Fordham University School of Law.

On Saturday, the Closing Plenary began with a brief signing ceremony to formalize a Memorandum of Understanding between the Society and the Organisation for Economic Cooperation and Development (OECD). The memorandum, signed by President Low and Gabriela Ramos, OECD Chief of Staff and Sherpa to the G20, provides for the two organizations to undertake a series of cooperative activities over the next several years. The ceremony was followed by a panel discussion on "The Future of Multilateralism," sponsored by the Embassy of the Netherlands in Washington, the Municipality of The Hague, and the Asser Institute for International and European Law. The program provided a fitting capstone to the conference, reaffirming the value and importance of the international legal system as a framework for global diplomacy and justice.

The success of the meeting was due to the creativity and commitment of many people, including President Lucinda A. Low, Annual Meeting co-chairs Kathleen Claussen, Jacob Katz Cogan, and Tafadzwa Pasipanodya, and the dedicated members of the Annual Meeting Committee. Thanks are also due to Deputy Executive Director Wes Rist, Director of Publications and Research, Caitlin Behles, the editor of these Proceedings, Erin Lovall, our meeting planner, Eden Capuano, and her team at Voila! Inc., our sponsors and partner organizations, and all the members of the Society's extraordinary staff.

MARK DAVID Agrast Executive Director

March 2019 Washington, DC 